\title{
Localization of disulfide bridges and free sulfhydryl groups in human eosinophil granule major basic protein
}

\author{
Claus Oxviga , Gerald J. Gleich ${ }^{\mathrm{b}}$, Lars Sottrup-Jensen ${ }^{\mathrm{a}, *}$ \\ a Department of Molecular Biology, University of Aarhus, C. F. Mollers Alle, Bldg. 130, DK-8000 Arhus C, Denmark \\ ${ }^{\mathrm{b}}$ Department of Immunology, Mayo Clinic, MN 55905, USA
}

Received 28 January 1994; revised version received 14 February 1994

\begin{abstract}
Eosinophil granule major basic protein (117 residues) is known to contain free sulfhydryl groups. Here we have located in the amino acid sequence the half-cystine residues present as cysteine, and identified those engaged in disulfide bridges. Of the 9 half-cystine residues, 5 are unpaired cysteines $\left(\mathrm{Cys}^{2}, \mathrm{Cys}^{23}, \mathrm{Cys}^{42}, \mathrm{Cys}^{64}\right.$, and $\left.\mathrm{Cys}^{96}\right)$, while 4 form disulfides $\left(\mathrm{Cys}^{20}-\mathrm{Cys}^{115}\right.$, and $\mathrm{Cys}^{92}-\mathrm{Cys}^{1{ }^{107}}$ ).
\end{abstract}

Key words: Eosinophil; Granule protein; Sulfhydryl group; Disulfide bridge

\section{Introduction}

Eosinophil leukocytes contain within their granules a number of cationic proteins, including major basic protein (MBP) [1,2]. MBP is the predominant protein in the eosinophil granule $[3,4]$ and forms the core of the granule $[5,6]$. MBP is cytotoxic to mammalian cells [7] and is implicated in the tissue damage associated with eosinophil infiltration, in particular damage to respiratory epithelium in asthma [8]. Also, the protein is toxic to parasites and is believed to play a key role in antiparasitic defense [9].

MBP has a molecular weight of $13.8 \mathrm{kDa}$ and a calculated pI of 10.9 [10]. From cDNA cloning it is known that MBP is synthesized as a larger precursor of 25.2 $\mathrm{kDa}$ (preproMBP) that is cleaved by an unknown mechanism in the cell to yield the mature protein $[11,12]$. While the mature protein is extremely basic, the proportion is quite acidic with a $\mathrm{pI}$ of 3.9 resulting in a near-neutral, putative proMBP molecule $(\mathrm{pI}=6.2$ ). It is hypothesized, that the pro-part functions to mask toxicity of mature MBP intracellularly [13]. MBP released from the eosinophil into plasma has been shown to bind to larger, yet unidentified proteins by disulfide bond formation [14]. The protein is known to possess reactive

* Corresponding author. Fax: (45) (8942) 2679

Abbreviations: CM, carboxymethyl; DTT, dithiothreitol; GuHCl, guanidinium chloride; HPLC, high-performance liquid chromatography; MBP, eosinophil granule major basic protein; PTH, phenylthiohydantion; RP, reversed-phase; TFA, triflouroacetic acid. sulfhydryl groups, but the number has not been determined $[10,15,16]$.

Curiously, it has been found that in serum of pregnant women MBP immunoreactivity rises throughout the period of gestation [17], and it has been shown recently that the molecule responsible for this is actually unprocessed proMBP [18]. In pregnancy, the source of proMBP is not the eosinophil, but rather placental X-cells $[19,20]$.

Here we report the status of the 9 half-cystine residues present in mature eosinophil MBP. The results show that MBP contains 5 free sulfhydryl groups and 2 disulfide bridges.

\section{Materials and methods}

\subsection{Proteins}

Major basic protein was purified from human eosinophils by isolating intact granules from lysed cells and extracting proteins with acid as previously described $[14,21]$. In the absence of reductant MBP slowly forms dimers and polymers $[15,16]$. To prevent oxidation of free sulfhydryl groups DTT was included in the acidic storage buffer $(25 \mathrm{mM}$ Na-acetate, $150 \mathrm{mM} \mathrm{NaCl}, 20 \mathrm{mM}$ DTT, pH 4.3). The material was kept frozen $\left(-80^{\circ} \mathrm{C}\right)$ for a few weeks. Porcine pepsin was from Worthington, and tosyl-phenylalanine chloromethylketone-treated bovine trypsin was from Cooper Biomedicals.

\subsection{Column materials and chemicals}

Sephadex G-25 SF was purchased from Pharmacia, and Nucleosil 100-5 C18 was from Macherey-Nagel. All standard chemicals were purchased from Merck or Sigma.

\subsection{Separation of peptides by RP-HPLC}

Peptides resulting from enzymatic degradation were separated on a Nucleosil C18 column $(0.4 \times 25 \mathrm{~cm})$ eluted at a flow rate of $1 \mathrm{ml} / \mathrm{min}$. A linear gradient, developed over $70 \mathrm{~min}$, was formed from $0.1 \%(\mathrm{v} / \mathrm{v})$ TFA (A) and $90 \%(\mathrm{v} / \mathrm{v})$ acetonitrile containing $0.075 \%(\mathrm{v} / \mathrm{v})$ TFA (B) 
$(0-50 \% \mathrm{~B})$. The column was operated at $50^{\circ} \mathrm{C}$, and the separation was monitored by recording the absorbance at $229 \mathrm{~nm}$.

\subsection{Amino acid analysis}

Amino acid compositions were determined by cation exchange following hydrolysis at $110^{\circ} \mathrm{C}$ for $18 \mathrm{~h}$ in sealed evacuated tubes containing $6 \mathrm{M} \mathrm{HCl}, 0.1 \%$ phenol, and $5 \%$ thioglycollic acid [22]. This system, a modification of one previously described [23], allows determination of cysteine without derivatization. Analysis was performed using $>200$ pmol material.

\subsection{Sequence analysis}

Edman degradations were performed on an Applied Biosystems 477A sequencer with an 120 on-line HPLC using a polybrene-coated glass filter or ProSpin sample preparation cartridge. Glass filters were precycled before sample application.

\subsection{Experimental details}

2.6.1. Alkylation. To remove DTT, $1 \mathrm{ml}$ of MBP $(1.8 \mathrm{mg} / \mathrm{ml})$ was thawed and desalted on a Sephadex G-25 SF column equilibrated and eluted with $25 \mathrm{mM} \mathrm{Na}$-acetate, $150 \mathrm{mM} \mathrm{NaCl}$, pH 4.3. The protein was recovered in a tube containing iodoacetic acid (final concentration 400 $\mathrm{mM}$ ), and the $\mathrm{pH}$ was raiscd over $20 \mathrm{~min}$; first to 7.0 by adding Tris base $(1 \mathrm{M})$, and then to $\mathrm{pH} 9.0$ by addition of $\mathrm{NaOH}(1 \mathrm{M})$. As known from previous results precipitation of MBP occurs at neutral pH [10]. To clear the solution and to alkylate potentially buried SH-groups, $\mathrm{GuHCl}$ was added to a final concentration of $6 \mathrm{M}$, and the solution was left for $90 \mathrm{~min}$ at room temperature in the dark. Afterwards, the material was dialyzed against $25 \mathrm{mM}$ Na-acetate, $150 \mathrm{mM} \mathrm{NaCl}$, pH 4.3 (unclear solution), and samples for amino acid and sequence analysis were removed. From non-reducing SDS-PAGE (not shown) it was estimated that $>95 \%$ of $\mathrm{MBP}$ was present as the $13.8 \mathrm{kDa}$ alkylated monomer.

2.6.2. Enzymatic digestion. After adjusting the $\mathrm{pH}$ to 2.0 by adding phosphoric acid, the dialyzed material was digested with pepsin (1:25 $(w / w))$ at $37^{\circ} \mathrm{C}$ for $20 \mathrm{~h}$. The clear solution of peptides was separated by RP-HPLC as shown below (Fig. 1). Peptide PCM5 (Table 1), dissolved in $100 \mathrm{mM} \mathrm{NH} 4 \mathrm{HCO} 3, \mathrm{pH} 8.7$, was further digested with trypsin $(1: 10(\mathrm{w} / \mathrm{w}))$ at $37^{\circ} \mathrm{C}$ for $20 \mathrm{~h}$.

\section{Results}

Major basic protein dissolved in acidic buffer containing DTT to preserve the free sulfhydryl groups (as explained above) was used as starting material. To prevent thiol-disulfide exchange reactions in the protein freed from DTT, it was mixed with iodoacetic acid, and the $\mathrm{pH}$ of the solution slowly increased. $\mathrm{GuHCl}$ was then added to ensure alkylation of potentially buried $\mathrm{SH}$-groups.

Alkylated protein was hydrolysed in reducing medium and from amino acid analysis the amount of CMCys and Cys present was estimated. Relative to 8 residues of leucine in MBP, we found 4.8 residues of CMCys and 4.3 residues of Cys (data not shown), corresponding to 5
Table 1

Half-cystine containing peptides identified in the peptic digest of alkylated MBP (Fig. 1)

\begin{tabular}{|c|c|}
\hline Peptide & Sequence $^{a}$ (residue numbers) \\
\hline PCM1 & TĈRYLL $(1-6)$ \\
\hline PCM2 & RIQČ́SVAL $(39-46)$ \\
\hline PCM3 & NQGQVWTGGRTTGSGRCRRFQWVDG $(48-72)$ \\
\hline PCM4 & ČTRGGY $(96-101)$ \\
\hline PCM $5^{\mathrm{b}}$ & $\begin{array}{l}\text { FTCRRČYRGNL }(18-28) \\
\text { WAAHQPWSRGGHCVAL }(80-95) \\
\text { WRRAHCLRRLPFICSY }(102-117)\end{array}$ \\
\hline
\end{tabular}

${ }^{\text {aHalf-cystines marked with an asterisk were unequivocally identified as }}$ CMCys by amino acid and sequence analysis.

'The 3 sequences of PCM5 were present in equimolar amounts as seen from amino acid and sequence analysis. From reducing hydrolysis the amount of Cys present was 4 times that of CMCys corresponding to one of the 5 half-cystines being present as CMCys. Sequence analysis revealed that either $\mathrm{Cys}^{23}$ or $\mathrm{Cys}^{107}$ was not part of a disulfide bridge since CMCys was seen in cycle 6. No information on the arrangement of the disulfide bridges could be obtained from sequencing PCM5.

half-cystines that had been susceptible to modification with iodoacetic acid and thus present as Cys, and 4 halfcystine residues engaged in disulfide bonds.

From sequence analysis of the alkylated MBP ( $28 \mathrm{cy}-$ cles) it was found that the half-cystines at position 2 and 23 were recovered as PTH-CMCys residues, and thus had been present as cysteine residues in native MBP. In contrast, no PTH derivative was found in cycle 20 suggesting that $\mathrm{Cys}^{20}$ was present in disulfide bridge linkage.

The alkylated MBP was digested with pepsin and the resulting peptides were separated by RP-HPLC as shown in Fig. 1. From amino acid and sequence analysis it was found that the peptides PCM1-4 contained $\mathrm{Cys}^{2}, \mathrm{Cys}^{42}$, $\mathrm{Cys}^{64}$, and $\mathrm{Cys}^{96}$, respectively, in the form of CMCys as shown in Table 1. The peptides shown were recovered in yields between $30 \%$ and $60 \%$. Besides PCM1-4 (and PCM5 discussed below), peptides not containing halfcystine corresponding to the rest of MBP were identified in comparable yields, and a few peptides that were variants of PCM1-4 were recovered in lower yields (not shown). Generally, only peptides in yields higher than approx. $5 \%$ were considered.

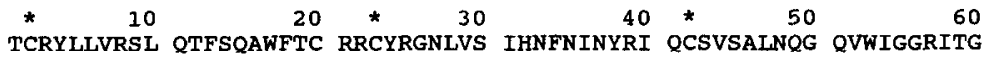

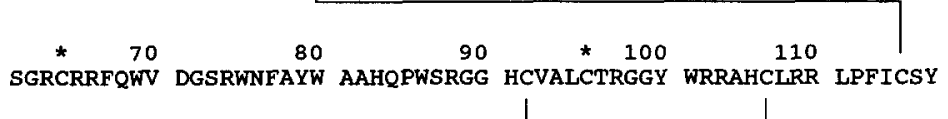

Fig. 1. Reversed-phase HPLC of peptic digest of alkylated MBP. A $0.4 \times 25 \mathrm{~cm}$ column packed with Nucleosil C18 $100-5$ was eluted with a linear gradient $(\cdots)$ formed from $0.1 \%(\mathrm{v} / \mathrm{v})$ TFA (A) and $90 \%(\mathrm{v} / \mathrm{v})$ acetonitrile containing $0.075 \%(\mathrm{v} / \mathrm{v})$ TFA (B). One third of the peptic digest (i.e. 0.6 mg MBP) was loaded, the absorbance was measured at $229 \mathrm{~nm}$, and fractions were collected manually. All fractions were analyzed and peptides containing CMCys or $\mathrm{Cys}_{2}$ were identified. The peptides shown in Table 1 are pointed out. Only fractions collected within the bar contained Cys as described in the main text. The time scale refers to the gradient. 


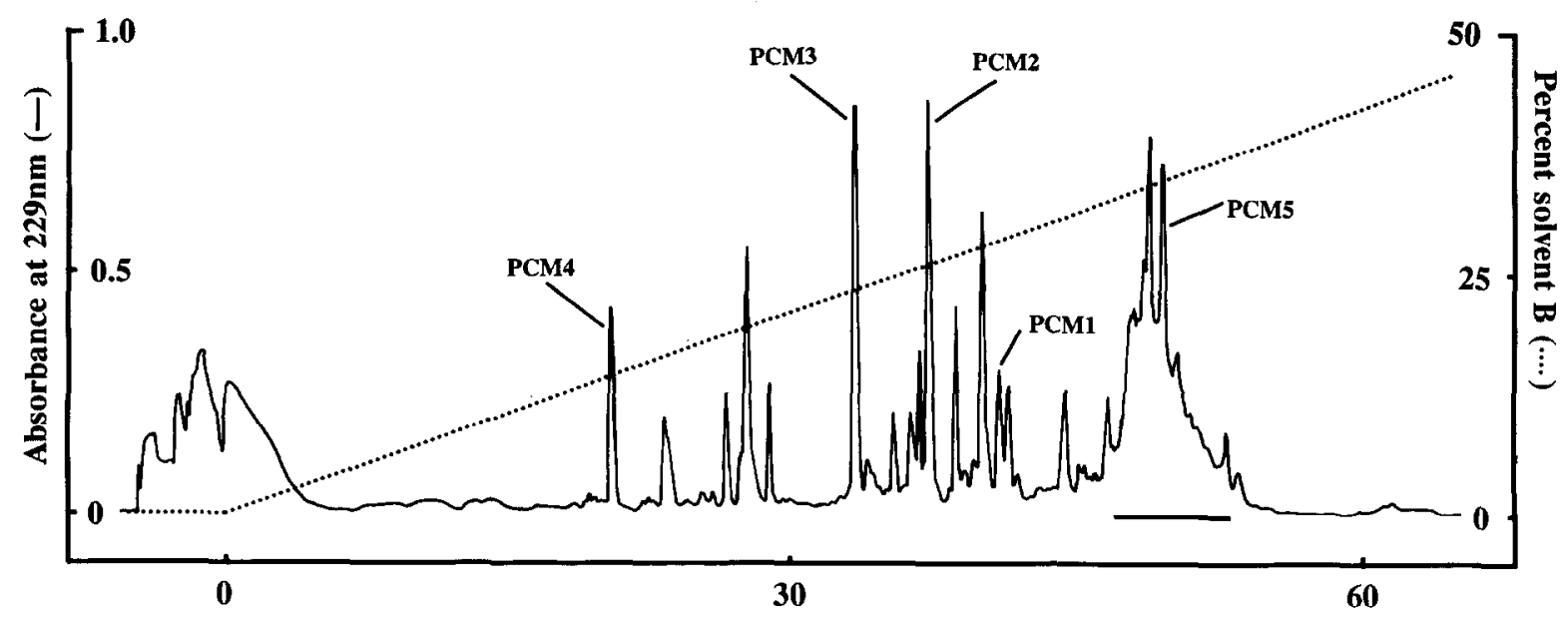

Time (min)

Fig. 2. Reversed-phase HPLC of tryptic digest of peptide PCM5. Identified half-cystine containing peptides shown in Table 2 are pointed out. Peptides arising from PCM5 were recovered in equimolar yields. The peaks marked a and b were identified as the tryptophan containing peptides WR (102-103) and WAAHQPWSR (80-88), respectively. Conditions for separation were as explained in legend to Fig. 1.

Of the peptides eluting before approx. $47 \mathrm{~min}$ from start of the gradient (Fig. 1), none were identified that contained $\mathrm{Cys}^{20}, \mathrm{Cys}^{23}, \mathrm{Cys}^{92}$, Cys ${ }^{107}$, or Cys ${ }^{115}$. These residues were recovered exclusively in fractions collected within the bar shown in Fig. 1. Amino acid and sequence analysis of the fraction corresponding to the peak marked PCM5 (Fig. 1) revealed the peptide set shown in Table 1. The $3 \mathrm{~N}$-termini were seen in equimolar amounts, and CMCys appeared in cycle 6 .

To reveal the arrangement of disulfide bonds in PCM5 it was digested with trypsin. Besides a variety of peptides not containing half-cystine only 3 peptides containing either CMCys or Cys were recovered following RPHPLC separation of the digest (Fig. 2). These peptides, all eluting as well defined peaks as a result of the specific cleavages obtained with trypsin, are shown in Table 2. The peptides were unequivocally identified by amino acid and sequence analysis. Thus, $\mathrm{Cys}^{23}$, in agreement with the sequence analysis of the undigested material, is

Table 2

Half-cystine containing peptides identified after tryptic digestion of PCM5 and separation by RP-HPLC (Fig. 2)

\begin{tabular}{ll}
\hline Peptide & Sequence $^{\text {a }}$ (residue numbers) \\
\hline PT1 & CYR $(23-25)$ \\
PT2 $^{\text {b }}$ & $\begin{array}{l}\text { GGHCVAL }(89-95) \\
\end{array}$ \\
AHCLR $(105-109)$ \\
PT3 $^{\text {b }}$ & FTCRR $(18-22)$ \\
& RLPFICSY $(110-117)$ \\
\hline
\end{tabular}

${ }^{2}$ The half-cystine residue marked with an asterisk was unequivocally identified as CMCys by amino acid and sequence analysis.

${ }^{\text {'Two sequences were seen in equimolar amounts, and bis-PTH-Cys }}$ was detected in steps 4 (PT2) and 6 (PT3). present as CMCys in alkylated MBP. Furthermore, $\mathrm{Cys}^{20}$ and $\mathrm{Cys}^{115}$ are connected by a disulfide bridge as are $\mathrm{Cys}^{92}$ and $\mathrm{Cys}^{107}$.

Also, fractions containing the remaining peaks within the bar shown in Fig. 1 were analysed. They were mainly variants of PCM5 shortened or elongated by one or a few residues. From tryptic digests of individual fractions only the same disulfide bound peptides and the stretch containing $\mathrm{Cys}^{23}$ could be recovered (not shown).

\section{Discussion}

This work presents experimental evidence that human eosinophil major basic protein contains 5 free sulfhydryl groups $\left(\mathrm{Cys}^{2}, \mathrm{Cys}^{23}, \mathrm{Cys}^{42}, \mathrm{Cys}^{64}\right.$, and Cys 96) and 2 disulfide bridges $\left(\mathrm{Cys}^{20}-\mathrm{Cys}^{115}\right.$, and $\mathrm{Cys}^{92}-\mathrm{Cys}^{107}$ ), as summarized in Fig. 3. It was recognized earlier that sulfhydryl groups are present in the molecule $[10,15,16]$, but to what extent had not been resolved.

During purification, storage, and processing of the native protein, it might be expected that thiol-disulfide exchange reactions could occur to a limited degree. However, all column fractions were analysed, and such potential rearrangements were not detected. It cannot be excluded that partial reduction has occurred in the presence of reductant, but the acidic $\mathrm{pH}$ of the storage buffer makes this unlikely. Some peptides were recovered as several variants due to the use of pepsin. In particular, peptide set PCM5 (Table 1) was seen in several different forms as described above.

It has been established that MBP is homologous with animal lectins, in particular the lectin domain of the low-affinity IgE receptor of lymphocytes, Fc $\varepsilon$ RII ( $31 \%$ identity) [24]. Further, on the basis of this homology it 


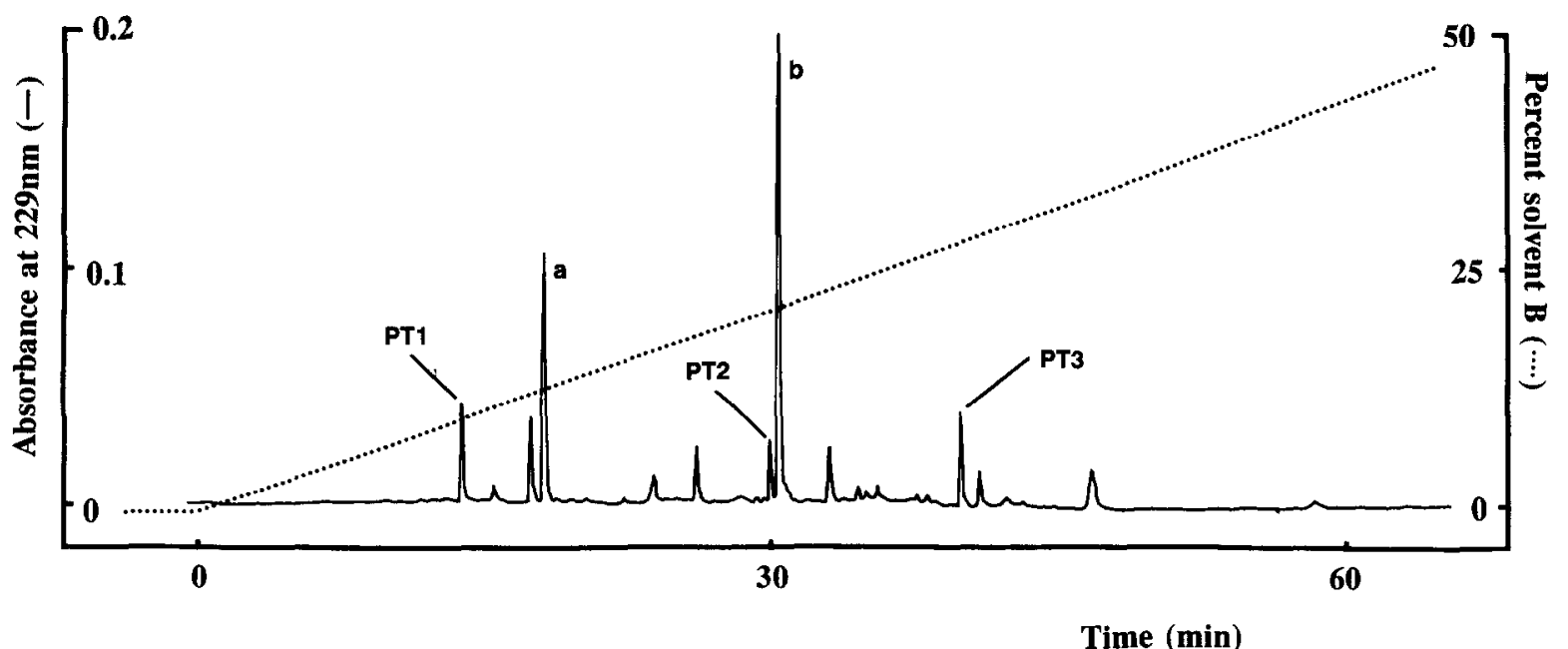

Fig. 3. Complete primary structure of human eosinophil major basic protein. Half-cystine residues bearing free sulfhydryl groups are marked with an asterisk $\left(\mathrm{Cys}^{2}, \mathrm{Cys}^{23}, \mathrm{Cys}^{42}, \mathrm{Cys}^{64}\right.$, and $\left.\mathrm{Cys}^{96}\right)$, and the 2 disulfide bridges $\left(\mathrm{Cys}^{20}-\mathrm{Cys}^{115}\right.$, and $\mathrm{Cys}^{92}-\mathrm{Cys}^{107}$ ) are shown by lines.

was suggested that MBP contains 2 disulfide bridges [24], those localized in the present work. The 5 half-cystine residues in MBP here shown to possess free sulfhydryl groups are all unique compared to other members of the animal lectin family, exemplified by the structure of human pancreatic stone protein and tetranectin $[25,26]$. In contrast to MBP, no other member is believed to contain free thiol groups.

In guinea pig, 2 forms of MBP have been recognized, GMBP1 and GMBP2 [27]. Comparison with the human sequence reveals that the 4 half-cystines engaged in disulfide bond formation are conserved in both guinea pig MBP forms. Regarding the unpaired half-cystines of human MBP, 4 are conserved in GMBP1 $\left(\mathrm{Cys}^{23}, \mathrm{Cys}^{42}\right.$, $\mathrm{Cys}^{64}$, and $\mathrm{Cys}^{96}$ ), while 3 are conserved in GMBP2 $\left(\mathrm{Cys}^{2}, \mathrm{Cys}^{23}\right.$, and $\left.\mathrm{Cys}^{96}\right)$.

The proform of MBP, proMBP, has recently been isolated from human pregnancy serum [18]. In pregnancy, the source of proMBP is placental X-cells rather than eosinophils $[19,20]$, and the protein found in serum is complexed to pregnancy-associated plasma protein-A (PAPP-A) [18]. Curiously, proMBP exists as a dimer in the complex with PAPP-A, a disulfide bond between the 2 residues corresponding to $\mathrm{Cys}^{2}$ in MBP being responsible in part [18]. In addition, at least one Cys residue in the pro-piece of proMBP further links to PAPP-A $[18,28]$. The complete arrangement of disulfide bonds in the complex (PAPP-A/proMBP) is not yet known.

MBP is unusual among the proteins related to animal lectins in having both free thiol groups and disulfide bridges. Whether the thiols in MBP play a role for the function of MBP as a cytotoxic molecule is not known.

Acknowledgements: This work was supported by the Danish Biomembrane Research Center and National Institute of Health Grant AI09728.

\section{References}

[1] Gleich, G.J. and Adolphson, C.R. (1986) Adv. Immunol. 39, 177253.

[2] Ackerman, S.J., Loegering, D.A., Venge, P., Olsson, I., Harley, J.B., Fauci, A.S. and Gleich, G.J. (1983) J. Immunol. 131, 29772982.

[3] Gleich, G.J., Loegering, D.A. and Maldonado, J.E. (1973) J. Exp. Med. 137, 1459-1471.

[4] Abu-Ghazaleh, R.I., Dunnette, S.L., Loegering, D.A., Checkel, J.L., Kita, H., Thomas, L.L. and Gleich, G.J. (1992) J. Leucoc. Biol. 52, 611-618.

[5] Peters, M.S., Rodriguez, M. and Gleich, G.J. (1986) Lab. Invest. $54,656-662$.

[6] Lewis, D.M., Lewis, J.C., Loegering, D.A. and Gleich, G.J. (1978) J. Cell. Biol. 77, 702-713.

[7] Gleich, G.J., Frigas, E., Loegering, D.A., Wassom, D.A. and Steinmuller, D. (1979) J. Immunol. 123, 2925-2927.

[8] Frigas, E. and Gleich, G.J. (1986) J. Allergy Clin. Immunol. 77, $527-537$.

[9] Butterworth, A.E., Wassom, D.L., Gleich, G.J., Loegering, D.A. and David, J.R. (1979) J. Immunol. 122, 221-229.

[10] Wasmoen, T.L., Bell, M.P., Loegering, D.A., Gleich, G.J., Prendergast, F.G. and McKean, D.J. (1988) J. Biol. Chem. 263, 1255912563.

[11] Barker, R.L., Gleich, G.J. and Pease, L.R. (1988) J. Exp. Med. $168,1493-1498$.

[12] McGrogan, M., Simonsen, C., Scott, R., Griffith, J., Ellis, N., Kennedy, J., Campanelli, D., Nathan, C. and Gabay, J. (1988) J. Exp. Med. 168, 2295-2308.

[13] Barker, R.L., Gundel, R.H., Gleich, G.J., Checkel, J.L., Loegering, D.A., Pease, L.R. and Hamann, K.J. (1991) J. Clin. Invest. 88, 798-805.

[14] Wassom, D.L., Loegering, D.A., Solley, G.O., Moore, S.B., Schooley, R.T., Fauci, A.S. and Gleich, G.J. (1981) J. Clin. Invest. 67, 651-661.

[15] Gleich, G.J., Loegering, D.A., Kueppers, F., Bajaj, S.P. and Mann, K.G. (1974) J. Exp. Med. 140, 313-332.

[16] Gleich, G.J., Loegering, D.A., Mann, K.G. and Maldonado, J.E. (1976) J. Clin. Invest. 57, 633-640.

[17] Wasmoen, T.L., Coulam, C.B., Leiferman, K.M. and Gleich, G.J. (1987) Proc. Natl. Acad. Sci. USA 84, 3029-3032. 
[18] Oxvig, C., Sand, O., Kristensen, T., Gleich, G.J. and SottrupJensen, L. (1993) J. Biol. Chem. 268, 12243-12246.

[19] Maddox, D.E., Kephart, G.M., Coulam, C.B., Butterfield, J.H., Benirschke, K. and Gleich, G.J. (1984) J. Exp. Med. 160, $29-41$.

[20] Bonno, M., Kephart, G.M., Carlson, C.M., Loegering, D.A., Vernoff, K.K. and Gleich, G.J., Lab. Invest., in press.

[21] Slifman, N.R., Loegering, D.A., McKean, D.J. and Gleich, G.J. (1986) J. Immunol. 137, 2913-2917.

[22] Sottrup-Jensen, L. (1993) Biochem. Mol. Biol. Int. 30, 789-794.

[23] Barkholt, V. and Jensen, A.L. (1989) Anal. Biochem. 177, 318322.
[24] Patthy, L. (1989) Mol. Immunol. 26, 1151-1154.

[25] Rouimi, P., de Caro, J., Bonicel, J., Rovery, M. and de Caro, A. (1988) FEBS Lett. 229, 171-174.

[26] Fuhlendorff, J., Clemmensen, I. and Magnusson, S. (1987) Biochemistry 26, 6757-6764.

[27] Aoki, I., Shindoh, Y., Nishida, T., Nakai, S., Hong, Y.-M., Mio, M., Saito, T. and Tasaka, K. (1991) FEBS Lett. 282, 56-60.

[28] Kristensen, T., Oxvig, C., Sand, O., Møller, N. P.H. and SottrupJensen, L., Biochemistry, in press. 